BEYOND PUBLIC PARTICIPATION: THE DISJUNCTURE BETWEEN SOUTH AFRICA'S ENVIRONMENTAL IMPACT ASSESSMENT (EIA) LAW AND SUSTAINABLE DEVELOPMENT

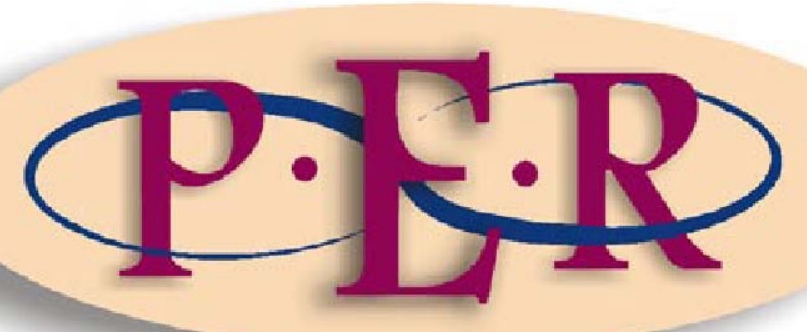

2008 VOLUME 11 No 3 


\section{BEYOND PUBLIC PARTICIPATION: THE DISJUNCTURE BETWEEN SOUTH AFRICA'S ENVIRONMENTAL IMPACT ASSESSMENT (EIA) LAW AND SUSTAINABLE DEVELOPMENT}

T Murombo*

\section{Introduction}

The way in which EIAs have been handled in South Africa has come a long way over the past twenty years. Government is committed to making even further improvements to the EIA system, which will ensure that our future economic growth occurs in a manner that does not compromise the integrity of our environment. ${ }^{1}$

South Africa is one of many countries worldwide that has taken steps to implement the global $^{2}$ call to take sustainable development ${ }^{3}$ seriously and to mainstream this concept in all development activities and policies. At the legal level, the country has enacted an array of impressive environmental legislation ${ }^{4}$

* Lecturer, School of Law, University of the Witwatersrand. An earlier version of this paper was awarded the 2007 Best Presentation, Early Career Researcher Award. See Murombo "Beyond Public Participation".

1 Statement by Marthinus Van Schalkwyk, the Minister of Environmental Affairs and Tourism in the Western Cape on Friday on 20 April 2007. The Minister referred to proposed amendments to the EIA regulations and s 24 of the National Environment Management Act 107 of 1998 (NEMA), in GN 392-395 GG 298624 May 2007. The draft bills seek to add certainty to the listed activities in GN 386 and 387 of 2006 (EIA Listed Activities).

2 Sustainable development remains a frequently debated concept at international law; see Magraw and Hawke "Sustainable Development" 613; Birnie and Boyle International Law 85, Osofsky 2003 LLA ICLR 111; and Hafner General Principles 53. However, in South Africa the concept has been given legal content and scope and is a legal principle, not just an ill defined norm (s 24 of the Constitution of the Republic of South Africa 1996, hereafter the Constitution; s 2 NEMA. The concept is viewed as a way to reconcile much-needed development and poverty alleviation with the need to protect the environment. Countries that have reformed their environmental legal frameworks to mainstream sustainable development include Australia, USA, UK, Kenya, Uganda and others.)

3 This concept is used throughout this paper as defined in WCED Our Common Future 43. Nevertheless I acknowledge the still highly debated meaning of the concept at the global level (see Murombo supra). At the domestic level South Africa's framework environmental law, the NEMA, defines the term as "the integration of social, economic and environmental factors into planning, implementation and decision-making so as to ensure that development serves present and future generations" (s 2).

4 This term refers to all the acts of Parliament and regulations that have something to do directly with the management of natural resources or the control of pollution and land-use 
not only aimed at conserving natural resources, but also more importantly targeting sustainable use of the few resources available to the ever-increasing population. ${ }^{5}$ An important development within this trend towards sustainable development is the development and implementation of laws and policies providing for environmental impact assessment (EIA) procedures. ${ }^{6}$ EIA is an important concept and procedure as it is one of the most effective tools or techniques for ensuring that development activities are sustainable. Whilst some argue that strategic environmental assessment (SEA) differs from EIA because the former is a broader process assessing the sustainability of policies, plans and programmes addressing social, economic and environmental outcomes, the South African approach to EIA has fruitfully coordinated the two processes. ${ }^{7}$ At least in theory, the result is that the projectspecific EIA procedure has as one of its objectives the attainment of sustainable development.

The EIA process in South Africa is integrative and holistic, addressing social, economic, and environmental or ecological issues concurrently. This approach has its own complications and strengths. A major strength is that the process seeks to achieve the integration which lies at the core of sustainable

planning. Examples include the National Environmental Management: Biodiversity Act 10 of 2004, the National Environmental Management Act: Air Quality Act 39 of 2004, the National Environmental Management Act: Protected Areas Act 57 of 2003 and the Waste Management Bill 2008 (in the pipeline).

5 S 24(b) of the Constitution imposes a positive duty on the state to take legislative and other measures to achieve sustainable development.

6 Wood Environmental Impact Assessment 1 defines EIA as "the evaluation of the effects likely to arise from a major project (or other action) significantly affecting the natural and man-made environment. Consultation and participation are integral to this evaluation"; whilst the UK EIA 2000 http://www.communities.gov.uk 28 Sep, defines it as "a means of drawing together, in a systematic way, an assessment of a project's likely significant environmental effects. This helps to ensure that the importance of the predicted effects, and the scope for reducing them, are properly understood by the public and the relevant competent authority before it makes its decision." In South Africa the NEMA does not define EIA but defines assessment, as when used in ch 5, as "the process of collecting, organising, analysing, interpreting and communicating information that is relevant to decision-making" GN R385 in GG 2875321 April 2006 (EIA regulations) made in terms of s 24 of this act amplifies this definition and provides that "in relation to an application to which scoping must be applied, [EIA means] the process of collecting, organising, analysing, interpreting and communicating information that is relevant to the consideration of that application".

7 See Magraw and Hawke, supra n 2, 635 on the distinction between sustainability assessment and EIA. 
development. An incipient weakness is the intricacy of any attempt to ensure that all the dimensions of an activity are adequately considered in the EIA process. ${ }^{8}$ A major premise of this paper is that the process of public participation can assist in unravelling this intricate process. Furthermore the EIA process becomes complicated, especially in developing countries, given the conflicting expectations of the state. In this regard these countries have to adapt legal instruments developed mainly in developed economies to take into account their own socio-economic circumstances. ${ }^{9}$ EIA assists the government to keep track of development activities that have the potential to cause significant adverse impacts on the environment, and to ensure that adequate mitigating measures are integrated into the planning of the project. While this development is commendable, one of the issues that remains of great concern is the extent to which the public participates in this process of ensuring that sustainable development ${ }^{10}$ is achieved. South Africa enacted EIA regulations in 2006 (hereafter "NEMA EIA regulations") $^{11}$ and one of the reasons for replacing the previous regulations was to ensure that there is more effective public participation in the EIA process. ${ }^{12}$ Development activities are not only supposed to be sustainable in the eyes of the proponent, but also in the view and perception of the public and local communities affected by the activities. ${ }^{13}$ In fact the socio-economic assessment of a proposal is an assessment of the impact of the proposal on the public's livelihood.

8 This is an issue that has preoccupied South African courts in many decisions culminating in Fuel Retailers Association of SA v Director-General, Environmental Management, Mpumalanga 20072 SA 163 (SCA) par 14, reversed by the Constitutional Court in 20076 SA 4 (CC); BP Southern Africa v MEC for Agriculture, Conservation, Environment \& Land Affairs 20045 SA 124 (W) and MEC for Agriculture, Conservation, Environment \& Land Affairs $v$ Sasol Oil 20065 SA 483 (SCA).

9 See generally Richardson and Woods Environmental Law 13.

10 Based on the now accepted definition of sustainable development, sustainability is used here as connoting the need to sustain not only resources, but also the social and economic aspects of life. To achieve sustainability a project must be capable of being sustained both economically and socially and - obviously - environmentally.

11 NEMA Environmental Authorisation Regulations GN R385-387 21 April 2006, effective 3 July 2006 by virtue of GN R612 23 June 2006.

12 The old regulations (promulgated as GN R1182-1184 1997 repealed by GN R615 GG 2893823 June 2006) were made under the now repealed Environment Conservation Act 73 of 1989 (ECA) see Field 2005 SALJ 763 (the public participation provisions in ECA EIA regulations were inadequate).

13 I use the terms "public" and "local communities" in a loosely intertwined manner. Local communities are necessarily conceived as being part of the public, whilst the notion of the public is broader than the notion of a local community. 
Participation by the public is crucial to the success of the EIA process and consequently also to the achievement of sustainable development. However, there is no agreed definition of what constitutes public participation. This is one of the constraining factors against effective participation in EIA processes, not only in South Africa but also in many other countries. ${ }^{14}$ Barton, ${ }^{15}$ whilst noting that there is no agreed definition of the concept of public participation, nevertheless correctly gives us factors that usually shape the nature of participation in most countries. He submits that:

[p]ublic participation is a matter of a nation's legal, political, and administrative arrangements, and therefore closer to the heart of national sovereignty than many other issues in international environmental law. How a nation wishes to conduct its public affairs is a very political matter.

He nevertheless points out that in the sphere of natural resources, development of international instruments like the Aarhus Convention can play a crucial role in shaping a global right to participation. ${ }^{16}$ The socio-political environment is an important aspect in the debate on sustainability. In South Africa the parameters and level of public participation are shaped not only by the legal and institutional framework, but also by other variables like the social and economic status of the citizens or interested and affected parties (I\&AP), as they are called under the NEMA EIA regulations. While public participation should aim to strike consensus or shared understandings, this may be difficult to achieve in a society with very wide gaps between the rich and the poor. The needs and concerns of these population groups are by no means homogeneous. ${ }^{17}$

14 See Barton Underlying Concepts for philosophical underpinnings of the idea of public participation and the absence of a common definition and link between EIA and public participation; see also Doelle and Sinclair 2006 EIA Rev 185 on the lack of consensus regarding the scope and meaning of public participation is one of the major shortcomings of the EIA processes in many countries.

15 Barton Underlying Concepts 84.

16 Convention on Access to Information, Public Participation in Decision-Making and Access to Justice in Environmental Matters (1999) 38 ILM 517, hereafter "the Aarhus Convention". See UNECE 2001 http://www.unece.org/env/pp/documents/cep43e.pdf 28 Sep. See also, Principle 10 of the Rio Declaration, UNEP 1992 http://www.unep.org/ 1 Oct.

17 These contradictions and controversies are well captured by Lindeque and Cloete 2005 Acta Structtilia 32 et seq; see also Bradshaw and Burger 2005 Africanus 46, advancing a conflict perspective of public participation and reiterating the deficiencies in South Africa's 
Consequently, what is socially or economically sustainable in the view of a particular section of the population is not necessarily sustainable in the view of other sections whose needs and aspirations may be different. ${ }^{18}$

In this paper I critically analyse the public participation ${ }^{19}$ provisions in the environmental impact assessment (NEMA EIA) ${ }^{20}$ regulations with specific reference to the extent to which they create more space for effective and informed public participation. Sustainable development may not be achieved without sustained and legally mandated efforts to ensure that development planning is participatory. Public participation allows for the integration of the socio-economic impacts of a project into the environmental decision-making process. I hypothesise that the provisions in the NEMA EIA regulations governing public participation illustrate a disjuncture between the regulatory framework and the idea of sustainable development as enshrined in South African environmental laws. ${ }^{21}$ To this end the second section of this paper consists of an exposition of the connection between the idea of sustainability, public participation and the EIA process. I seek to show that while there is a connection between sustainability and EIA on the one hand and the notion of public participation on the other, such a connection must be reinforced by

public participation process before the NEMA EIA regulations, as well as the link between sustainable development and EIA.

18 For instance the different views expressed regarding the construction of a super railway link called the Gautrain illustrate the diverse views on sustainability obtaining in South Africa. Whereas the majority of the predominantly affluent residents of the northern suburbs supported the development, many poor people thought the project was a waste of resources that could be used to provide other immediate needs like housing and transport to the large, struggling, poor population living mainly in the southern locations. This is not to discount the views of some Greens, who can be said to be rich but who still think the project is a waste of resources and therefore not economically sustainable.

19 I refrain from engaging in a detailed critique of the seemingly exhausted debate on the theoretical and philosophical underpinnings of the idea of public participation itself. Extensive research has been done in various contexts and this paper focuses on the legislative attempt to use the concept as a democratic governance tool. See generally Ebbesson "Public Participation" 686; Ventriss and Kuentzel 2005 IJOTB 520, arguing that public participation may in fact limit the boundaries of effecting change under the guise of democracy, using Jurgen Habermas' and David Harvey's theories.

20 Supra $\mathrm{n} 11$.

21 It has since been argued that the EIA regulations are informed and shaped by crude "environmentalism" instead of being grounded in the idea of "sustainable development". This issue is not revisited in this paper (see generally Field supra n 12, 409 and authorities there cited). Here I focus on the lack of effective public participation as one of the indicators of the overemphasis on environmentalism instead of sustainability. 
clearly defined legal provisions. This theoretical framework will be applied in the third section to analyse the public participation provisions in the NEMA EIA regulations with a view to assessing their potential to contribute towards sustainability. I also briefly highlight the role that courts can play in adding certainty to ambiguous legal provisions, and how they have helped enforce the EIA laws in South Africa. Lastly I draw conclusions on possible legal reforms that can be made to South Africa's EIA regulations to ensure that the public participation procedures work to the benefit of sustainable development. ${ }^{22}$

Being an instrument of social engineering, law can effectively be used to reconcile diverse interests and promote development that meets the legitimate expectations of a diverse society without necessarily compromising standards (set by law). Development needs to meet not only the expectations of current generations but also of posterity. To fully understand the complexities of this role of the environmental law it is necessary to unravel the connection, if any, between the norms of sustainability, public participation and the EIA process.

\section{Sustainability, EIA and public participation: What is the link?}

It is generally accepted that one of the main objectives behind EIA processes is to ensure that any development that is authorised will not have significant impacts on the environment. The concept of the "environment" in South African environmental law is widely defined to include the social, economic and cultural environments. ${ }^{23}$ The aim of averting significant adverse impacts is to ensure that development is sustainable. According to Wood, consultation and participation are integral appendages of the EIA process because they lie at the centre of studies to establish social and economic sustainability. ${ }^{24}$ In South Africa the concept of sustainable development is included in the supreme law of the land, the Constitution, as one of the objectives of the fundamental right to regulations, and this paper is seen as part of that process.

23 S 1(xi) NEMA; s 1 ECA.

24 Wood, supra n 6, 1. 
an environment that is not harmful to health and well-being. ${ }^{25}$ Acting on its duty imposed by section 24(b) to put in place legislative and other measures to promote, among other things, ecologically sustainable development, the government of South Africa enacted the National Environment Management Act 107 of 1998, an overarching statute, which applies generally to all environmental matters. Together with court decisions, the NEMA is important because it elaborates on the concept of sustainable development in South Africa, even though in international law the concept's meaning remains disputed and the subject of much debate. ${ }^{26}$ In its preamble this act opens by stating that -

sustainable development requires the integration of social, economic and environmental factors in the planning, implementation and evaluation of decisions to ensure that development serves present and future generations,

and further includes sustainable development among key principles of environmental management that must guide government policy and decision-making. ${ }^{27}$

The amplification of sustainable development in section 2(4) of the NEMA virtually includes all of the emerging and established principles of environmental law as principles that are geared towards sustainable

25 S 24 of the Constitution provides that: "Everyone has the right - (a) to an environment that is not harmful to their health or well-being; and $(b)$ to have the environment protected, for the benefit of present and future generations, through reasonable legislative and other measures that - (i) prevent pollution and ecological degradation; (ii) promote conservation; and (iii) secure ecologically sustainable development and the use of natural resources while promoting justifiable economic and social development". (Own emphasis.) This right must be read together with the right of access to information (s 32) and the right to just administrative action (s 33) which supplement and strengthen the procedural rights of citizens, in this case, regarding the administration of environmental laws, including laws that regulate the EIA process.

26 See supra $\mathrm{n}$ 2; see also Fuel Retailers Association of SA $v$ Director-General, Environmental Management, Mpumalanga 20072 SA 163 (SCA); 20076 SA 4 (CC) and BP Southern Africa v MEC for Agriculture, Conservation, Environment \& Land Affairs 2004 5 SA $124(W)$.

27 Own emphasis. S 2 (3) provides that, "[d]evelopment must be socially, environmentally and economically sustainable" ss (4) (a) then adds that "[s]ustainable development requires the consideration of all relevant factors including the [generally accepted emerging and established principles of environmental law]"; par (i) to (viii), then (f) and (g) list principles which include the precautionary principle, the principle of prevention, environmental justice, public participation, polluter pays, integrated environmental management and many others. 
development. It is important for the purpose of this study to note that sections 2(4)(f) and (g) provide for the principle of public participation as one of the factors which must be considered if sustainable development is to be achieved. These sections provide that:

f) The participation of all interested and affected parties in environmental governance must be promoted, and all people must have the opportunity to develop the understanding, skills and capacity necessary for achieving equitable and effective participation, and participation by vulnerable and disadvantaged persons must be ensured.

g) Decisions must take into account the interests, needs and values of all interested and affected parties ... ${ }^{28}$

The connection between EIA as a strategy for the implementation of integrated environmental management and public participation is therefore put beyond doubt by statute. ${ }^{29}$

However, the link with public participation is by no means clear. Does the involvement of members of the public necessarily make the development process that they are engaged in sustainable? If not, why then is public engagement necessary? It is submitted that the concept of sustainable development focuses on the needs of people and the need to limit development to sustainable levels. To understand needs and to properly determine whether a given project meets the needs of any generation it is important for the opinions of that generation to be heard. More importantly, public engagement brings with it accountability and transparency, qualities that may make it difficult for project proponents to externalise the environmental costs of development

28 Own emphasis.

29 Field supra $\mathrm{n} 12,761$. Note, however, that at one stage the $\mathrm{CC}$ dampened the spirits by ruling that these NEMA principles do not create substantive rights but are merely there to guide decision-making by government departments, see Minister of Public Works $v$ Kyalami Ridge Environmental Association 20013 SA 1151 (CC). However, with the Fuel Retailers decision, supra $\mathrm{n} 8$, par 67, the court unequivocally stressed the significance of these principles. Bradshaw and Burger, supra $n$ 17, 48, however, argue that "[i]f sustainability is to be the goal [of public participation], it is the function of public participation to assist decision makers to establish the point of sustainability for each project by contributing essential local knowledge and wisdom to project planning and design, and by clarifying the degree to which stakeholders are willing to accept or live with the trade-offs". 
activities. Public scrutiny can lead to good decisions and therefore sustainable decisions. This assumes that the level and degree of participation is of a certain quality and depth. Thus EIA as a technique of implementing sustainable development is one of the effective frameworks within which public participation in environmental decision-making can take place. ${ }^{30}$ Public participation is also indispensable in other environmental decision-making processes like law-, policy- and rule-making.

What remains unsatisfactory in South African law is the scope and procedures for public participation provided for in the NEMA EIA regulations. The NEMA does not define the idea of "public participation". ${ }^{31}$ Admittedly this is a difficult concept to define for all purposes, but Spyke correctly concludes that "[i]n its broadest form, participation can include education and information, review and reaction, and interaction and dialogue". ${ }^{32}$ The NEMA EIA regulations define it as "a process in which potential interested and affected parties are given an opportunity to comment on, or raise issues relevant to, specific matters". ${ }^{33}$ It is apposite to add that this model of participation has long been perceived as being inadequate and elitist to the extent that it assumes that technocrats and experts are the only people competent to design and develop projects and present them to the public for acceptance which generally takes the form of rubberstamping. ${ }^{34}$ By endorsing what Jones appropriately called the "decide-

30 Barton, supra n 14, 78.

31 Nel 2001 SAJELP 110.

32 Spyke 1999 BCEALR 267.

33 EIA regulations supra $n 6$, reg 1(1). Ch 6 of the regulations is dedicated to the public participation procedure. This represents a fundamental improvement on the ECA regulations which cursorily provided for a public participation process which was at best least defined, and at worst vague and left to the discretion of the EIA practitioner. See generally the now repealed GN R1183 5 September 1997: Activities identified under s 21(1) [ECA] in the schedule - reg 3(1)(f) which provided that the project applicant "is responsible for the public participation process, to ensure that all interested parties, including government departments that may have jurisdiction over any aspect of the activity, are given the opportunity to participate in all relevant procedures contemplated in [the] regulations". (Own emphasis). In Earthlife Africa (Cape Town) v Director-General: Department of Environmental Affairs and Tourism 20053 SA 156 (C) par 59 the court construed the emphasised words to mean that the public were entitled to comment at all stages of the EIA, including on the final Environmental Impact Report.

34 In describing this rational, elite notion of participation in governance Barton, supra n 14, 85 expresses the opinion that "an elite has little enthusiasm for public participation. Even a democratic form of elitism, based on rationality and official expertise, sees no need for public participation in solving problems; it knows the answers itself." 
announce-and-defend decision-making" ${ }^{35}$ model the NEMA EIA regulations fail to mainstream one of the essential elements of sustainable development. As provided in section 2 of the NEMA, sustainability requires decision-making processes to include effective participation by the public, not only by endorsing decisions about the type of development desired, but also in making the most appropriate and therefore sustainable choices. This issue will be addressed further in the following section, in which I deal specifically with the procedures for public participation.

Before analysing the EIA process itself, it is worth noting that the concept of the "public" is broadly defined in the NEMA EIA regulations, under the term "interested an affected" parties. The term "interested and affected party" is defined in the regulations as follows,

...interested and affected party contemplated in section 24(4) (d) of the Act, [and which in terms of that section] includes -

a) any person, group of persons or organisation interested in or affected by an activity; and

b) any organ of state that may have jurisdiction over any aspect of the activity.

It is doubtful whether this attempt to define the "public" who may participate in the EIA process, albeit broad, will include all potentially affected members of the public. It has been argued that it is better not to attempt to define the "public" who must participate in the EIA process. ${ }^{36}$ The danger of exclusion is a real possibility, but it is submitted that in some cases it may not be necessary to include even people whose interests in the project are so remote that they are unlikely to suffer any significant impacts from the project. ${ }^{37}$ Hamann gives an example of the sometimes counterproductive role played by environmental non-

35 Jones 1997 W\&M ELPR 25

36 Doelle and Sinclair, supra n 14, 96: "Any definition of the public brings with it the inherent risk of excluding someone who should be allowed to participate. The only justification for exclusion that seems acceptable is someone who is motivated by a desire to make the process fail."

37 I would not go so far as advocating a scoping process where some issues raised by some participants can be disregarded as insignificant before they are fully considered or at the stage of setting the terms of reference for the EIA. See Ross et al 2006 IA\&PA 5. 
governmental organisations (NGOs), which almost invariably appear to be oppositional to development activities. ${ }^{38}$ On the other hand, there should be no harm in allowing any interested person to participate and make inputs into proposed development activities, in accordance with the democratic governance process. ${ }^{39}$ It is argued that given the elusive nature of the concept of the "public" it is better to err on the side of caution by adopting an all-inclusive notion. An exclusive notion may lead to project delays and unnecessary costs, as some of those excluded challenge the process.

To be effective, participation must not be a once-off event, but a sustained, iterative process, which commences with problem identification and goes on to project conception or formulation, and approval. It appears that the public participation process contemplated by chapter 5 of the NEMA read with chapter 6 of the EIA regulations ends with the granting or rejection of authorisation. ${ }^{40}$ Once interested and affected parties have made their contribution through the process leading up to the preparation of the EIA and decision by the competent authority, the only remedy remaining, should they be dissatisfied, is to appeal against or seek a review of the process leading to the decision. ${ }^{41}$ This remains a fundamental defect in the EIA process, as non-compliance or departures from EIA reports and mitigation measures must be monitored. It can safely be argued that public participation is also crucial during project implementation and monitoring, but in order to be able to participate the public requires access to information regarding the authorisation conditions of the project. An analysis of the innovation introduced by the NEMA EIA regulations in relation to public participation would be necessary to illuminate and fortify the shortcomings thereof highlighted above.

38 Hamann 2003 SAJELP 21.

39 See generally Masango 2002 Politeia 52 for the argument that public participation is generally essential to democratic policy implementation and good governance.

40 This can be said to illustrate the overemphasis on process rather than outcomes which Doelle and Sinclair, supra n 14, 186 identify as one of the major sources of problems in EIA processes.

41 EIA regulations, supra $n$ 6, regs 10 and 60(2). The internal appeal against a decision by a competent authority may be available in limited circumstances. However, the aggrieved party will have to appeal under the Promotion of Administrative Justice Act 3 of 2000 (PAJA) against a decision of the MEC or Minister. 


\section{The NEMA EIA legal framework}

The NEMA EIA regulations were first published in April 2006 and they became effective 3 July $2006 .{ }^{42}$ The main objectives of revising the EIA procedure were not only to address the inadequacies of the ECA EIA regulations but also to take into account continuous developments in sustainable development law and sustainability discourse, and contemporary issues of participatory governance as encapsulated in the NEMA principles. ${ }^{43}$ Generally speaking the NEMA EIA regulations provide for a two-pronged approach to EIA, namely a process for what one can term minor projects (called a Basic Assessment ) and another for major or more complex projects (called Scoping). ${ }^{44}$ It is the responsibility of the Environmental Assessment Practitioner (EAP) to assess any particular project and determine whether it should be assessed using the Basic Assessment or Scoping and EIA. ${ }^{45}$ The EAPs are bound in terms of regulation 18 of GN R385 to be independent and objective even though they are retained and paid by the person seeking authorisation. Whether or not they in fact exercise such independence may be cause for concern.

In addition to the main regulations providing for the EIA process, two more regulations were promulgated identifying, through a process of listing, the activities that must undergo either EIA processes. ${ }^{46}$ There are advantages and disadvantages to this listing approach, which has the propensity of being either over or under inclusive. ${ }^{47}$ This process was carried over from the ECA EIA regulations but under the NEMA EIA regulations the lists have been better

42 EIA regulations, supra $\mathrm{n} 6$.

43 Glazewski Environmental Law in South Africa. See also Nel, supra n 31. The rights of interested and affected parties were poorly defined in the now repealed GN R1182-1184 GG 182615 September 1997.

44 In terms of EIA regulations, supra n 6, reg 21, activities listed under GN R386 undergo a Basic Assessment, while those listed under GN R387 must be subjected to Scoping and EIA. Both processes are subject to the public participation process required by EIA regulations, supra $\mathrm{n} 6$, reg 56.

45 EIA regulations, supra n 6, reg 20(1). The decision is guided by the guidelines developed by the Department of Environmental Affairs and Tourism. See DEAT Guideline No 3.

46 GN R386 and 3872006.

47 Glazewski, supra n 43, 385 raises this as a defect of the now repealed ECA regulations GN 11821997. 
thought out and organised, providing details of the nature of the activity that must be assessed. For instance, the listing regulations identify the activities by name, type, size and capacity. It is submitted though that these criteria are by no means unambiguous. I It remains an issue as to whether some peripheral or borderline activities are susceptible to EIA or not. This is one of the reasons why there are already proposals to amend these regulations to remove any uncertainty regarding the listed activities. ${ }^{48}$ In addition regulations $72-75$ of GN 385 give the national and provincial governments powers to formulate nonbinding guidelines that clarify the provisions of the regulations, which proponents must follow.

If an activity is listed in GN R386 of 2006 then it does not require extensive Scoping. It is enough to do a Basic Assessment. Projects on this list are perceived as not likely to have significant impacts on the environment. The anticipated impacts are easily foreseeable, miniscule and manageable, and therefore it is deemed not necessary to delay project implementation by requiring extensive assessment. On the other hand GN R387 of 2006 lists activities which are complex and expected to have significant or unforeseeable impacts on the environment, and therefore require detailed assessment through the Scoping process. Essentially, this schema represents the approach adopted in many other countries, consisting of the broad processes of screening, scoping, assessment, reporting, decision-making or authorisation, and post-authorisation review and monitoring. ${ }^{49} \mathrm{~A}$ Basic Assessment seems to end at the screening stage, while Scoping continues with scoping, assessment, reporting and authorisation.

It is important to note that in terms of the regulations the public should be consulted during the EIA study and must be given the opportunity to comment on the EIA reports. Recently the courts confirmed that the public are also

48 GN 393 GG 298624 May 2007, supra n 1. These lists will also be amended to add certainty and remove ambiguity if the proposed bill is passed by Parliament. 
entitled to comment on the final report and not only the draft report. ${ }^{50}$ This is intended to ensure that the final report submitted to the competent authority has properly taken into account the comments from the public. A critical handicap of the public participation process mandated by the NEMA EIA regulations is that they provide no more guidance other than the size, contents, and place of publication of notices to I\&APs. ${ }^{51}$ The provision that the practitioner can issue the notice to the I\&APs after making the application for authorisation or before is quite worrying. ${ }^{52}$ It must be noted that in most cases this is the first stage at which the I\&APS get involved and get any information that an EIA is being or will be carried out. This negates a number of key stages in the EIA process, such as the need to consider alternatives. Thus consideration of alternatives after this stage is merely wasting time, as a decision would have already been made to go for a particular project design and location. Unsurprisingly therefore the Constitutional Court in Fuel Retailers Association of Southern Africa $v$ Director-General Environmental Management, Department of Agriculture, Conservation and Environment, Mpumalanga Province, recently ruled that development must take into account the needs of society as expressed by members of the public, who must be given the opportunity to participate in the decision-making process. ${ }^{53}$

\subsection{Project conception and consideration of alternatives}

Unsustainable projects or activities are unsustainable from the time they are designed or formulated. No amount of public involvement after the design and formulation of a project will cure a particular project of its unsustainability, whether during implementation or after completion when the project is

50 Earthlife Africa (Cape Town) v Director-General: Department of Environmental Affairs and Tourism 20053 SA 156 (C) par 68-69.

51 Reg 56(3) contents of the notice, ie, whether application has already been lodged, type of assessment to be done or already done, description of location of activity. Reg 56(4) (of the notice) reg 56(6): "When complying with this regulation, the person conducting public participation process must ensure that the information containing all relevant facts in respect of the application is made available to potential interested and affected parties; and participation by potential interested and affected parties is facilitated in such a manner that all potential interested and affected parties are provided with a reasonable opportunity to comment on the application."

$52 \operatorname{Reg} 56(3)(b)$.

5320076 SA 4 (CC) par 60 and 70. 
operating. It has correctly been argued therefore that the critical moment is the stage of project design, which must not be left to corporations and their experts. $^{54}$ In particular, if the project is to offer a service or good to the community, whether a public or private service, it is best to have the input and comments of the ultimate users before sinking resources into the research and design of the project. ${ }^{55}$ Such resources are better spent first on getting the opinions and ideas of the affected community on whether the proposed project is the best way to address the identified problem. In this respect Doelle and Sinclair aptly argue that -

[b]y encouraging collaboration and giving equal opportunity to all interested parties to provide input to the project design and potential resulting impacts, the process itself should ensure the project makes a net contribution to sustainability. ${ }^{56}$

More often than not, corporations and government departments sink a lot of funds into research and development, then design solutions to problems without consulting the users or the public, and then present the proposal as a fait accompli or the best solution to the problem. The assumption is that the proposed solutions are also the best solutions in the eyes of the public, yet this is not invariably true. Obviously this relates to activities and projects that are by law required to undergo EIA and not every conceivable development activity. Most alternatives provided in justifying the chosen option have rightly been labelled as "pseudo-alternatives" by others in other jurisdictions. ${ }^{57}$

All too often this is an error which is hard to reverse, given the resources already spent in researching and developing the solution outside the eyes of the public or consumers. ${ }^{58}$ This is where unsustainability begins, where industry

54 Barton, supra n 14.

55 Fuel Retailers decision, supra n 8, par 76. The public through participation processes help determine the sustainability of an activity.

56 Own emphasis. Doelle and Sinclair, supra $\mathrm{n} 14,188$.

57 Pardo 1997 EIA Rev 134 commenting on the EIA process in Spain which broadly falls under the European Directive 85/337/EEC effective in Spain in from 1988. Note that public participation in the European Union including in EIA processes should now ideally be premised on the Aarhus Convention on Public Participation.

58 Under regs 23 (2) (g) and 32(2) (f) both basic and EIA reports must contain "a description of the need and desirability of the proposed activity and any identified alternatives to the 
directs the process of development, giving little regard to social and environmental sustainability and the acceptability to the public of the proposed development. Wood submits that the ideal generic EIA process usually consists of the following steps:

- a consideration of alternative means of achieving objectives;

- designing the selected proposal;

- determining whether an EIA is necessary in a particular case (screening);

- deciding on the topics to be covered in the EIA (scoping);

- preparing the EIA report (that is, inter alia, describing the proposal and the environment affected by it and assessing the magnitude and significance of impacts);

- reviewing the EIA report to check its adequacy;

- making a decision on the proposal, using the EIA report and opinions expressed about it; and

- monitoring the impacts of the proposal if it is implemented. ${ }^{59}$

It is important to note that the first step identified by Wood is to consider the various alternative approaches to solving the problem or achieving the objective sought. A good illustration of the failure to do this in South Africa is where a power utility, having identified that there is likely to be power shortages in the country, researches the options open to it to increase generation capacity. The utility would usually consider its options and choices usually within the limits of the resources available to it, other constraints, and the cost implications. It decides to restart coal-fired power plants that had been switched off when power generation was producing a surplus. It also proceeds to construct new coal-fired power plants. ${ }^{60}$ This is despite the fact that the country is among the global top emitters of green-house gases which are fuelling the much talked

proposed activity that are feasible and reasonable, including the advantages and disadvantages that the proposed activity or alternatives will have on the environment and on the community that may be affected by the activity (own emphasis). This is required, but only in the report submitted to the competent authority.

59 Wood, supra n 6, 5.

60 See eg Eskom 2007 http://www.eskom.co.za/content/ 21 Jun. 
about climate change. ${ }^{61}$ To make matters worse, the country's share of carbon emissions come mostly from energy production processes.

Clearly, the decision to continue to use coal-fired power plants and build even more is environmentally unsustainable. Even though, given the development status and other developmental goals of the country, the decision may seem to be the most sustainable choice to make, it cannot be justified without further interrogation. In particular, it may be wondered whether the energy utility considered using the funds and resources in the promotion of renewable energy. What about solar energy for lighting and gas for cooking? These processes account for much of the increased demand arising from population growth and economic growth. If at least the energy mix could include more renewable energy for lighting and heating then the remaining capacity might be enough to satisfy the demands of industry. One acknowledges the typical constraints that governments and industries in developing countries face, such as insufficient revenue and the need to alleviate poverty. For instance, South Africa is trying hard to alleviate energy poverty and the social and economic predicaments that arise in a situation of energy poverty. These constraints may militate against religious fidelity to the EIA laws when such projects are being implemented. For instance, it may not be possible to allow public engagement to solve the energy crisis. It is submitted, though, that these are not insurmountable challenges, and that they must not be readily used as excuses for excluding the public from environmental decision-making. ${ }^{62}$ Even if the public were to suggest better alternatives to such activities, it does not seem likely that the government or the corporations would back down and choose such alternatives. To the EAP, alternatives in the case of power plants for example connote alternative routes for the transmission lines and facility siting,

61 South Africa produces 40\% of Africa's aggregate carbon emissions, see CSL Forum 2007 http://www.cslforum.org/safrica.htm 21 Jun. It was in the top 25 emitters as of 2000 see Baumert, Herzog and Pershing 2005 http://pdf.wri.org/ 21 Jun. See also The Stern Review http://www.hm-treasury.gov.uk/ 1 Oct. Power production contributes most to greenhouse gas emissions.

62 A defect emanating from the regulations, see reg 56. See also Richardson and Razzaque, Public Participation 192, which argues that many deficiencies with public participation can be traced to flaws in the enabling legal and institutional frameworks. Another example is the recent development of a nuclear energy policy by the DME without adequate public participation in its conception. 
but clearly, consideration of alternatives includes alternatives to the type of development envisaged as the solution to the problem - in this case, an overextended power supply.

What remains clear from the above examples is that the new EIA regulations provide for inadequate participation in project design and the suggestion of alternatives. Instead they entrench the old approach of leaving the design and conception of the project to experts. ${ }^{63}$ This elitism must end if sustainability in all its forms (social environmental and economic) is to be achieved, and if delays through court challenges are to be avoided.

\subsubsection{Post authorisation dilemmas and sustainability}

The project referred to above also illustrates that the proponent is usually faced with unending court challenges once the project is authorised. Assuming the good faith of the litigators, this is an indicator of the fact that the public remains dissatisfied by the participation process. For instance the decision to authorise the construction of the Eskom Matimba B (Medupi) power plant was appealed against. This administrative appeal was determined by the Minister of Environmental Affairs and Tourism under the NEMA EIA regulations and best illustrates this point. ${ }^{64}$ Most impacts only become clear once project implementation begins. Even those that may have been deemed environmentally insignificant can with the passage of time materialise as major environmental problems necessitating extensive revision of some components of the project, without necessarily repeating the assessment. In most cases the public will no longer have room to participate in ensuring that the proponent sticks to the design and procedures approved on authorisation of the project. Often, in the absence of effective post-authorisation monitoring, proponents will take short cuts and ignore costly mitigation measures which they would have undertaken

63 Some have added that when the experts present the project proposals they gloss over their adverse impacts, glorifying their social and economic benefits. See Pardo, supra $\mathrm{n}$ 57, 135-136.

64 See MCM 2008 http://www.mcm-deat.gov.za/press/2007/07052007.html 1 Oct. See also Holman 2008 http://www.engineeringnews.co.za/ 1 Oct. 
to take in the EIA reports. While this can be remedied by effective enforcement by environmental agencies, an informed public can be a good watchdog.

The assessment of the economic sustainability of an activity must look not only at the needs of the proponents but also at the needs of the public. Benefits in this context do not refer only to material benefits but also to environmental goods and services provided or environmental costs and hazards avoided. For instance, the construction of new power plants works to the benefit of the public if in fact after construction it improves the supply of energy or lowers the cost of energy. On the other hand if the cost of electricity does not go down and the power plants add to carbon emissions the net impact on the public consists of added health hazards from pollution including the prospect of suffering from the effects of climate change.

\section{The role of the courts in promoting sustainable development}

The inadequacies of the EIA process in South Africa can be ameliorated if the judiciary plays its role in ensuring that only activities that are proven to be sustainable after an EIA are approved. Even activities that appear to be unsustainable may still be approved if adequate mitigation measures and environmental management plans are put in place to minimise the residual impacts. Of late the courts in South Africa have indeed proved that they can be a force to reckon with in the face of an under-resourced government department overwhelmed by EIA applications. A detailed discussion of the approach which the courts have taken is beyond the scope of this paper and has been discussed extensively elsewhere. ${ }^{65}$ Suffice it to note that sustainability hinges to a significant extent on the availability of judicial remedies and access to justice.

A number of court decisions illustrates that the courts are aware of the need to foster sustainable development in their sphere of influence. In decisions 
concerning the authorisation of fuel stations, courts have shown their readiness by settling the controversy concerning whether an EIA should include socioeconomic considerations. ${ }^{66}$ The courts are crucial since they eventually settle most disputes that arise during the EIA process regarding the absence or inadequacy of the public participation process, for instance. Furthermore, the courts are important as they give substance to legislation through interpretation in practical cases. Thus in the Earthlife ${ }^{67}$ decision the court unequivocally elaborated on the nature of public participation, detailing to what extent the public is to be engaged with, what type of information they are entitled to, and what protection there is for project proponents.

In the final analysis the courts are the custodians of the Constitution, which is the basis of the right to an environment not harmful to health and well-being, which right is implemented through the NEMA and the EIA process it enacts. ${ }^{68}$

\section{Thoughts for the future: A climate for change}

The above analysis shows that indeed public participation has a critical role to play in facilitating sustainability. However, in order for public participation to effectively play this role, the legal provisions providing for opportunities for participation must not limit the opportunity to procedural involvement but require that sustained efforts be made to ensure that the public earnestly engage in development decisions.

While I have argued that public participation is necessary for the achievement of sustainable development, a persistent issue remains as to how to measure

66 See Fuel Retailers decision, supra n 8, referring to ss 2, 3,4 of NEMA and applying MEC for Agriculture, Conservation, Environment \& Land Affairs v Sasol Oil 20065 SA 483 (SCA). For a comparative discussion of decisions prior to the Fuel Retailers case, see Petersen, supra n. 64.

67 Earthlife Africa (Cape Town) v Director-General: Department of Environmental Affairs and Tourism 20053 SA 156 (C). This case and the role of the courts in promoting public participation are extensively discussed by Field supra $\mathrm{n} 12$.

68 See Fuel Retailers decision, supra n 8, par 102 and MEC: Department of Agriculture, Conservation and Environment v HTF Developers 2008 (4) BCLR 417 (CC) par 28 where the $\mathrm{CC}$ reiterated its crucial role in promoting sustainable development generally. 
sustainability. Many authorities have grappled with this issue in various ways. Whilst indicators and models have been developed and are being experimented with, the issue remains elusive. ${ }^{69}$ The EIA process in South Africa provides an opportunity to ensure the sustainability of development projects and activities, but the law mandating this process is still wanting in respect of public participation. No clear-cut criterion for measuring the sustainability of activities has yet been developed. The problems discussed in this paper are compounded by other variables peculiar to the socio-economic environment of developing countries. Pertinent factors include the accessibility of information and the reports prepared by EAPs. ${ }^{70}$ The matter of accessibility relates $t$ to the issue of language as well as to the issue of availability. In most cases the EIA reports and project documents are prepared using technical and complex language which the ordinary person may not understand without the assistance of experts. The NEMA EIA regulations do not clearly require reports and documents to be made available in the language of choice of the interested and affected parties, this being a matter at the discretion of the EAP. Furthermore, whether the language of the documents should be simplified or not is a matter not clearly regulated.

\section{Conclusion}

I have argued in this article that South Africa is among the few developing countries that have seriously taken to implementing the concept of sustainable development. Challenges still remain in terms of putting in place clear and effective regulations providing for effective public participation. This is particularly so with regard to the recently promulgated regulatory framework for environmental impact assessments. The article has shown that while the

69 See Birnie and Boyle, supra n 2, 85 on parameters of sustainability and criteria not yet clear; Blackburn Sustainability Handbook; Pinter, Hardi and Bartelmus Sustainable Development Indicators 2005; Hardi and Zdan 1997 http://www.iisd.org/pdf/bellagio.pdf 28 Sep; Bossel 1999 http://www.iisd.org/pdf/balatonreport.pdf 28 Sep, suggesting how sustainability indicators can be developed and applied.

70 See generally Ebbesson, supra n 18, 696-701, which discusses the importance of access to information, minimum standards and access to justice for effective public participation in environmental decision-making generally. 
existence of the regulations and their further refinement in 2006 are commendable, much can be done to enhance public participation. Public participation is a necessary condition for ensuring the sustainability of development activities.

The theory of public participation, which is currently focused on notice and comment procedures, must give way to a nuanced and sustained participatory framework, which ensures that the public participates from the early stages of project design, and also after authorisation. I have elaborated on the inevitable complementary nexus that exists between a participatory environmental decision-making processes and the achievement of sustainable development. Sustainability is ultimately measured by reference to what the citizens or public consider to be sustainable given their social, economic and political circumstances before and after project implementation. This is especially the case in relation to the social, cultural and economic impacts of a project, whether the impacts are anticipated or residual. However, all too often the propensity for project proponents and government departments is to presume to know what is sustainable and therefore in the best interest of the citizens. This engenders conflict and lack of confidence in the developmental state. The judiciary can play a role in this regard by progressively interpreting legal instruments and giving content to the ideals embodied in environmental legislation. South African courts have shown their preparedness to play this critical role. However, the measurement of what is or is not sustainable remains a challenge as universal indicators are still under development, and cannot be applied across time and across countries. 


\section{Bibliography}

Barton Underlying Concepts

Barton B "Underlying Concepts and Theoretical Issues in Public Participation in Resources Development" in Zillman DN et al (eds) Human Rights in Natural Resource Development Public Participation in the Sustainable Development of Mining and energy Resources (Oxford University Press Oxford 2002)

Birnie and Boyle International Law

Birnie PW and Boyle AE International Law and the Environment $2^{\text {nd }}$ ed (Oxford University Press Oxford 2002)

Blackburn Sustainability Handbook

Blackburn WR The Sustainability Handbook Complete Management Guide to Achieving Social Economic and Environmental Responsibility

(Environmental Law Institute Washington DC 2007)

Bradshaw and Burger 2005 Africanus

Bradshaw G and Burger W "Public Participation, Sustainable Development and Public Disputes: Public scoping processes in the Coega deep water port and industrial zone" 2005 (35) Africanus 44-57

\section{DEAT Guideline No 3}

DEAT Guideline No 3: General to the EIA Process (Government Printers Pretoria 2006)

Doelle and Sinclair 2006 EIA ReV

Doelle $\mathrm{M}$ and Sinclair $\mathrm{J}$ "Time for a new approach to public participation in EA: Promoting cooperation and consensus for sustainability" 2006 (26) Environmental Impact Assessment Review 185-205

Ebbesson "Public Participation"

Ebbesson J "Public Participation" in Bodansky D, Brunnéé J and Hey E (eds) The Oxford handbook of International Environmental Law (Oxford University Press Oxford 2007) 


\section{Field 2005 SALJ}

Field TL "Public Participation in Environmental Decision-making: Earthlife Africa (Cape Town) v Director-General: Department of Environmental Affairs and Tourism" 2005 (122) South African Law Journal 748-765

Field 2006 SALJ

Field TL "Sustainable Development versus Environmentalism: Competing Paradigms for the South African EIA Regime" 2006 (123) South African Law Journal 409-436

Glazewski Environmental Law in South Africa

Glazewski J Environmental Law in South Africa $2^{\text {nd }}$ ed (LexisNexis Butterworths Durban 2005)

Hafner General Principles

Hafner G "General Principles of Sustainable Development: From Soft Law to Hard Law" in Fitzmaurice M and Szuniewicz M (eds) Exploitation of Natural Resources in the $21^{\text {st }}$ Century (Kluwer Law International Hague 2003)

Hamann 2003 SAJELP

Hamann R "South African challenges to the theory and practice of public participation in environmental assessment" 2003 (10) South African Journal of Environmental Law and Policy 21-32

Jones 1997 W\&M ELPR

Jones EG "Risky Assessments: Uncertainties in Science and the Human

Dimensions of Environmental Decision-making" 1997 (22) William and Mary Environmental Law and Policy Review 3-25

Kidd 1999 SAJELP

Kidd M "The National Environment Management Act and Public Participation" 1999 (6) South African Journal of Environmental Law and Policy 21-31 
Lindeque and Cloete 2005 Acta Structtilia

Lindeque AS and Cloete CE "Public participation in lower and higher socioeconomic areas in South Africa" 2005 (12) Acta Structtilia 25-41

Magraw and Hawke "Sustainable Development"

Magraw DB and Hawke LD "Sustainable Development" in Bodansky D,

Brunnéé J and Hey E (eds) The Oxford handbook of International

Environmental Law (Oxford University Press London 2007)

Masango 2002 Politeia

Masango R "Public Participation: A Critical Ingredient of Good Governance" 2002 (21) Politeia 2002 52-65

Murombo "Beyond Public Participation"

Murombo T "Beyond Public Participation: The Disjuncture Between South

Africa's Environmental Impact Assessment (Eia) Law And Sustainable

Development" Papers delivered at the Australia New Zealand Society of

Ecological Economics Conference 2-6 July (Noosaville Australia 2007)

Nel 2001 SAJELP

Nel J "Stakeholder Relationships in the EIA Process: Some concerns" 2001

(8) South African Journal of Environmental Law and Policy 105-110

Osofsky 2003 LLA ICLR

Osofsky HM "Defining Sustainable Development after the Earth Summit 2002" 2003 (26) Loyola of Los Angeles International and Comparative Law Review 91-111

Osorio 2005 ED\&S

Osorio LS et al "Debates on Sustainable Development: Towards a Holistic View of Reality" 2005 (7) Environment, Development \& Sustainability 501518

Pardo 1997 EIA Rev

Pardo M "Environmental Impact Assessment: Myth or Reality? Lessons from Spain" 1997 (17) Environmental Impact Assessment Review 123-142 


\section{Petersen 2006 SALJ}

Paterson A "Fuelling the Sustainable Development Debate in South Africa" 2006 (123) South African Law Journal 53-62

Pinter, Hardi and Bartelmus Sustainable Development Indicators Pinter L, Hardi P and Bartelmus P Sustainable Development Indicators: Proposals for the Way Forward (discussion paper prepared under a consulting agreement on behalf of the UN Division for Sustainable Development; Winnipeg, Canada: International Institute for Sustainable Development 2005)

Richardson and Razzaque Public Participation

Richardson BJ and Razzaque J "Public Participation in Environmental Decision-making" in Richardson BJ and Woods S (eds) Environmental Law for Sustainability (Hart Publishing Oxford 2006)

Richardson and Woods Environmental Law

Richardson BJ and Woods S "Environmental Law for Sustainability" in Environmental Law for Sustainability (Hart Publishing Oxford 2006)

Ross et al 2006 IA\&PA

Ross WA et al "Common Sense in Environmental Impact Assessment: It is not as common as it should be" 2006 (24) Impact Assessment and Project Appraisal 3-10

\section{Spyke 1999 BCEALR}

Spyke NP "Public Participation in Environmental Decision-making at the New Millennium: Structuring New Spheres of Public Influence" 1999 (26) Boston College Environmental Affairs Law Review 263-272

Ventriss and Kuentzel 2005 IJOTB

Ventriss C and Kuentzel W "Critical Theory and the Role of Citizen Involvement in Environmental Decision Making: A re-examination" 2005 (8) International Journal of Organization Theory and Behaviour 519-539 
WCED Our Common Future

World Commission on Environment and Development Our Common Future (Oxford University Press Oxford 1987)

Wood Environmental Impact Assessment

Wood C Environmental Impact Assessment: A Comparative Review

(Longman Harlow 1995)

\section{Register of legislation}

Constitution of the Republic of South Africa Act 1996

Environment Conservation Act 73 of 1989

GN 392-395 Government Gazette 298624 May 2007

GN R1182-1184 Government Gazette 182615 September 1997

GN R385-387 Government Gazette 2875321 April 2006

GN R615 Government Gazette 2893823 June 2006

National Environmental Laws Amendment Bill 2007

National Environmental Management Act 107 of 1998

National Environmental Management Act: Air Quality Act 39 of 2004

National Environmental Management Act: Protected Areas Act 57 of 2003

National Environmental Management Amendment Act 8 of 2004

National Environmental Management: Biodiversity Act 10 of 2004

Promotion of Administrative Justice Act 3 of 2000

Waste Management Bill 2008

\section{List of court cases}

BP Southern Africa (Pty) Ltd v MEC for Agriculture, Conservation, Environment \& Land Affairs 20045 SA 124 (W)

Earthlife Africa (Cape Town) v Director-General: Department of Environmental Affairs and Tourism 20053 SA 156 (C)

Fuel Retailers Association of SA (Pty) Ltd v Director-General, Environmental Management, Mpumalanga, and Others 20072 SA 163 (SCA)

Fuel Retailers Association of SA (Pty) Ltd v Director-General, Environmental Management, Mpumalanga, and Others 20076 SA 4 (CC)

Hichange Investments (Pty) Ltd v Cape Produce Co (Pty) Ltd t/a Pelts Products 20042 SA $393(E)$ 
MEC for Agriculture, Conservation, Environment \& Land Affairs v Sasol Oil (Pty) Ltd 20065 SA 483 (SCA)

MEC: Department of Agriculture, Conservation and Environment and Another $v$ HTF Developers (Pty) Ltd 2008 (4) BCLR 417 (CC)

Minister of Public Works and Others $v$ Kyalami Ridge Environmental Association and Another 20013 SA 1151 (CC)

Muckleneuk/Lukasrand Property Owners and Residents Association v MEC Department of Agriculture Conservation and Environment Gauteng Provincial Government and Others (Review Application 28192/04) Muckleneuk/Lukasrand Property Owners and Residents Association v HOD Department of Agriculture Conservation and Environment Gauteng Provincial Government and Others (Urgent Application 12137/06) (28192/04; 12137/06) [2006] ZAGPHC 86 (30 August 2006) Silvermine Valley Coalition $v$ Sybrand van der Spuy Boerderye and Others 20021 SA 478 (C)

\section{Register of international and regional instruments}

Convention on Access to Information, Public Participation in Decision-Making and Access to Justice in Environmental Matters 1999

Rio Declaration on Environment and Development - United Nations Declaration on Environment and Development 1992

United Nations Declaration on Environment and Development 1992

\section{Register of internet sources}

Baumert, Herzog and Pershing 2005 http://pdf.wri.org/ 21 Jun Baumert KA, Herzog T and Jonathan Pershing J 2005 Navigating the Numbers: Greenhouse Gas Data and International Climate Policy [Found on internet] http://pdf.wri.org/navigating numbers chapter2.pdf [Date of use 21 June 2007]

Bossel 1999 http://www.iisd.org/pdf/balatonreport.pdf 28 Sep

Bossel H 1999 Indicators for Sustainable Development: Theory Method and Applications: A Report to the Balaton Group [Found on internet] http://www.iisd.org/pdf/balatonreport.pdf [Date of use 28 September 2008] 
CSL Forum 2007 http://www.cslforum.org/safrica.htm 21 Jun

CSL Forum 2007 An Energy Summary of South Africa [Found on internet]

http://www.cslforum.org/safrica.htm [Date of use 21 June 2007]

Eskom 2007 http://www.eskom.co.za/content/ 21 Jun

Eskom 2007 The Matimba B (Medupi) Transmission Integration Project

Scoping Report [Found on internet] http://www.eskom.co.za/content/294-

02\%20SR\%20MatimbaDelta\%2030-04-07v4.pdf [Date of use 21 June 2007]

Hardi and Zdan 1997 http://www.iisd.org/pdf/bellagio.pdf 28 Sep

Hardi P and Zdan T 1997 Assessing Sustainable Development: Principles in Practice [Found on internet] http://www.iisd.org/pdf/bellagio.pdf [Date of use 28 September 2008]

Holman 2008 http://www.engineeringnews.co.za/ 1 Oct

Holman J 2008 Transmission lines threaten ecotourism: action group

[Found on internet] http://www.engineeringnews.co.za/article.php?a id=

134710 [Date of use 1 October 2008]

MCM 2008 http://www.mcm-deat.gov.za/press/2007/07052007.html 1 Oct

MCM 2008 Appeal Decision by Minister of Environmental Affairs and Tourism on the Construction of the Proposed Eskom Holdings Limited Generation Division 4800 MW Coal Fired Power Station and Associated Infrastructure near the Lephalale Area, Limpopo Province (Matimba B) [Found on internet] http://www.mcm-deat.gov.za/press/2007/07052007.html [Date of use 1 October 2008]

Stern Review http://www.hm-treasury.gov.uk/ 1 Oct HM Treasury "Stern Review on the Economics of Climate Change" [Found on internet] http://www.hm-treasury.gov.uk/independent reviews/stern review economics climate change/sternreview index.cfm [Date of use 1 October 2008]

UK EIA 2000 http://www.communities.gov.uk 28 Sep

UK Environmental Impact Assessment 2000 A guide to procedures 
(Queens Printer and Controller HMSO 2000) [Found on internet] http://www.communities.gov.uk [Date of use 28 September 2008]

UNECE 2001 http://www.unece.org/env/pp/documents/cep43e.pdf 28 Sep

UNECE 2001 Convention on Access to Information, Public Participation in Decision-Making and Access to Justice in Environmental Matters [Found on internet] http://www.unece.org/env/pp/documents/cep43e.pdf [Date of use 28 September 2008]

UNEP 1992 http://www.unep.org/ 1 Oct

UNEP 1992 Rio Declaration on Environment and Development [Found on internet] http://www.unep.org/Documents.multilingual/Default.asp? Document ID=78\&Article|D=116 [Date of use 1 October 2008]

\section{List of abbreviations}

$\begin{array}{ll}\text { ANSZEE } & \text { Australia New Zealand Society of Ecological Economics } \\ \text { CC } & \text { Constitutional Court } \\ \text { ch } & \text { chapter(s) } \\ \text { DEAT } & \text { Department of Environmental Affairs and Tourism } \\ \text { DME } & \text { Department of Minerals and Energy } \\ \text { EAP } & \text { Environment Assessment Practitioner } \\ \text { ECA } & \text { Environment Conservation Act } \\ \text { EIA } & \text { Environmental Impact Assessment } \\ \text { ESKOM } & \text { Electricity Supply Commission (English) } \\ \text { I\&APs } & \text { Interested and Affected Parties } \\ \text { NEMA } & \text { National Environmental Management Act } \\ \text { NGO(s) } & \text { non-governmental organisation(s) } \\ \text { PAJA } & \text { Promotion of Administrative Justice Act } \\ \text { par } & \text { paragraph(s) } \\ \text { reg } & \text { regulation(s) } \\ \text { S } & \text { section(s) } \\ \text { Sch } & \text { schedule(s) } \\ \text { SEA } & \text { strategic environmental assessment } \\ \text { UN-DSD } & \text { United Nations Division for Sustainable Development }\end{array}$


UNECE United Nations Economic Commission for Europe

UNEP

United Nations Environment Programme

WCED

World Commission on Environment and Development 